\title{
Hydrometallurgical Process and Economic Evaluation for Recovery of Zinc and Manganese from Spent Alkaline Batteries
}

\author{
Lan-Huong Tran *, Kulchaya Tanong, Ahlame Dalila Jabir, Guy Mercier and Jean-François Blais $\mathbb{B}$ \\ Institut National de la Recherche Scientifique (Centre Eau, Terre et Environnement), Université du Québec, \\ 490 rue de la Couronne, Québec, QC G1K 9A9, Canada; kulchaya.tanong@ete.inrs.ca (K.T.); \\ ahlame_dalila.jabir@ete.inrs.ca (A.D.J.); guy.mercier@ete.inrs.ca (G.M.); jean-francois.blais@ete.inrs.ca (J.-F.B.) \\ * Correspondence: lan.huong.tran@ete.inrs.ca; Tel.: +418-654-2550; Fax: +418-654-2600
}

Received: 17 July 2020; Accepted: 26 August 2020; Published: 1 September 2020

\begin{abstract}
An innovative, efficient, and economically viable process for the recycling of spent alkaline batteries is presented herein. The developed process allows for the selective recovery of $\mathrm{Zn}$ and Mn metals present in alkaline batteries. The hydrometallurgical process consists of a physical pre-treatment step for separating out the metal powder containing $\mathrm{Zn}$ and $\mathrm{Mn}$, followed by a chemical treatment step for the recovery of these metals. Sulfuric acid was used for the first leaching process to dissolve $\mathrm{Zn}$ (II) and $\mathrm{Mn}$ (II) into the leachate. After purification, Mn was recovered in the form of $\mathrm{MnO}_{2}$, and $\mathrm{Zn}$ in its metal form. Furthermore, during the second sulfuric acid leaching, $\mathrm{Na}_{2} \mathrm{~S}_{2} \mathrm{O}_{5}$ was added for the conversion of $\mathrm{Mn}(\mathrm{IV})$ to $\mathrm{Mn}$ (II) (soluble in the leachate), allowing $\mathrm{Mn}$ to be recovered as $\mathrm{MnCO}_{3}$. Masses of $162 \mathrm{~kg}$ of $\mathrm{Zn}$ metal and $215 \mathrm{~kg}$ of $\mathrm{Mn}$ (both in the form of $\mathrm{MnO}_{2}$ and $\mathrm{MnCO}_{3}$ ) were recovered from one ton of spent alkaline batteries. The direct operating costs (chemicals, labor operation, utilities, energy) and indirect costs (amortization, interest payment) required for a plant treating 8 tons of spent batteries per day was calculated to be \$CAD 726 and \$CAD 534 per ton, respectively, while the total revenue from the sale of the metals was calculated at \$CAD 1359.6 per ton of spent batteries. The development of this type of cost-effective industrial process is necessary for a circular economy, as it contributes to addressing environment- and energy-related issues, and creates opportunities for the economic utilization of metals.
\end{abstract}

Keywords: spent alkaline battery; recycling; leaching; electrowinning; hydrometallurgy; techno-economic evaluation; metal recovery

\section{Introduction}

The use of electronic compact devices with batteries such as remote controls, watches, electric toys, and pocket lamps has become an integral part of our society. Furthermore, these batteries have a certain lifetime, and the increase in volume of spent batteries over the last few years requires an innovative recycling process. Findings from research into metal recovery in recent years indicate the importance of recycling spent batteries [1-8]. In Canada, Call2recycle collected more than $2.5 \mathrm{kt}$ of batteries for recycling in 2017 and $2.7 \mathrm{kt}$ in 2018, of which 78\% consisted of alkaline and $\mathrm{Zn}-\mathrm{C}$ batteries [9]. However, the collected quantity only represents approximately $20 \%$ of all batteries sold in the market [10]. Alkaline batteries consist of a negative zinc metal electrode and a positive manganese dioxide $\left(\mathrm{MnO}_{2}\right)$ electrode with an alkaline potassium hydroxide electrolyte, instead of the acidic ammonium chloride electrolyte used in zinc-carbon batteries. After collection, batteries are separated by type and sent to appropriate processing plants. Alkaline and carbon zinc batteries are sent to Retriev (Trail, BC, Canada), Inmetco (Elwood City, PA, USA), Raw Materials Company 
(Port Colbone, ON, Canada), and Battery Solutions Recovery (Brighton, MI, USA), where the batteries are treated by pyrometallurgical processes $[10,11]$. These processes separate metals by volatilization and melting, and, therefore, require high-energy consumption and, due to the release of toxic gases, require an additional collection/cleaning system. By contrast, hydrometallurgical processes usually have a lower energy consumption and lower environmental impacts than pyrometallurgical processes. Hydrometallurgical processes consist of metal leaching followed by the separation, purification, and recovery of valuable metals through various techniques including, among others, precipitation, solvent extraction, and electrowinning. Numerous studies have used leaching processes under various conditions for the leaching of $\mathrm{Zn}$ and $\mathrm{Mn}$ from battery powder (Table 1).

Table 1. Leaching yields of $\mathrm{Zn}$ and $\mathrm{Mn}$ from alkaline battery by acid leaching.

\begin{tabular}{|c|c|c|c|c|c|}
\hline \multirow{2}{*}{ Leaching Agent } & \multirow{2}{*}{ Auxiliary Agent } & \multirow{2}{*}{ Conditions } & \multicolumn{2}{|c|}{ Metal Removal (\%) } & \multirow{2}{*}{ Ref. } \\
\hline & & & $\mathrm{Zn}$ & Mn & \\
\hline $\mathrm{H}_{2} \mathrm{SO}_{4} 0.54 \mathrm{M}$ & $\mathrm{H}_{2} \mathrm{O}_{2} 4 \%(v / v)$ & $2 \mathrm{~h}, 55^{\circ} \mathrm{C}, 1 / 30 \mathrm{w} / v$ & 100 & 95.7 & \multirow{2}{*}{ [12] } \\
\hline $\mathrm{H}_{2} \mathrm{SO}_{4} 0.54 \mathrm{M}$ & $\mathrm{H}_{2} \mathrm{O}_{2} 4 \%(v / v)$ & $2 \mathrm{~h}, 55^{\circ} \mathrm{C}, 1 / 10 w / v$ & 53.8 & 42.8 & \\
\hline $\mathrm{H}_{2} \mathrm{SO}_{4} 0.5 \mathrm{M}$ & Ascorbic acid $10 \mathrm{~g} / \mathrm{L}$ & \multirow{3}{*}{$3 \mathrm{~h}, 25^{\circ} \mathrm{C}, 1 / 20 w / v$} & 99.5 & 98.8 & \multirow{3}{*}{ [13] } \\
\hline $\mathrm{H}_{2} \mathrm{SO}_{4} 0.5 \mathrm{M}$ & Citric acid $10 \mathrm{~g} / \mathrm{L}$ & & 99.9 & 91.6 & \\
\hline $\mathrm{H}_{2} \mathrm{SO}_{4} 0.5 \mathrm{M}$ & Oxalic acid $10 \mathrm{~g} / \mathrm{L}$ & & 96.4 & 87.5 & \\
\hline $\mathrm{H}_{2} \mathrm{SO}_{4} 1.5 \mathrm{M}$ & \multirow{3}{*}{-} & $3 \mathrm{~h}, 80^{\circ} \mathrm{C}, 1 / 10 \mathrm{w} / v$ & 90 & $<20$ & \multirow{3}{*}{ [14] } \\
\hline $\mathrm{H}_{2} \mathrm{SO}_{4} 1.0 \mathrm{M}$ & & Microwave 1 cycle, $30 \mathrm{~s}$ & 94 & $<20$ & \\
\hline $\mathrm{H}_{2} \mathrm{SO}_{4} 1.0 \mathrm{M}$ & & $\begin{array}{c}\text { Ultrasonic, } 2 \text { min, } \\
0.1 \text { pulse, } 20 \% \text { amplitude }\end{array}$ & 92 & $<20$ & \\
\hline $\mathrm{H}_{2} \mathrm{SO}_{4} 1.5 \mathrm{M}$ & $\begin{array}{l}\text { Lactose twice } \\
\text { of stoichiometry }\end{array}$ & $3 \mathrm{~h}, 90^{\circ} \mathrm{C}, 1 / 10 w / v$ & 100 & 98 & [15] \\
\hline Bio-generated $\mathrm{H}_{2} \mathrm{SO}_{4}$ & $\begin{array}{c}\mathrm{H}_{2} \mathrm{O}_{2} 5 \text { vol. } \% \text { or } \\
\mathrm{Na}_{2} \mathrm{SO}_{3} 1 \mathrm{wt} . \% \\
\text { Calcine } 2 \mathrm{~h}, 750{ }^{\circ} \mathrm{C}\end{array}$ & $2 \mathrm{~h}, 30^{\circ} \mathrm{C}, 1 / 25 w / v$ & 99 & $90-98$ & [16] \\
\hline
\end{tabular}

Notably, the respective reaction time, temperature, acid concentration, and solid/liquid (S/L) ratio should be compared, as these parameters vary across the different studies. Sulfuric acid is commonly used either singly or in combination with an auxiliary agent. For example, the addition of $\mathrm{H}_{2} \mathrm{O}_{2}(4 \% \mathrm{v} / \mathrm{v})$ in a sulfuric acid solution was used to remove $100 \%$ of $\mathrm{Zn}$ and $95.7 \%$ of $\mathrm{Mn}$ from battery powder [12]. In another study, the combination of ascorbic acid with sulfuric acid led to the dissolving of $99.5 \%$ of $\mathrm{Zn}$ and $98.8 \%$ of $\mathrm{Mn}$ [13]. Although the use of an auxiliary agent is key to dissolving $\mathrm{Mn}$ in sulfuric acid, results from a study where no auxiliary agents were used indicate a $90 \%$ removal of $\mathrm{Zn}$ and less than 20\% removal of $\mathrm{Mn}$ in a sulfuric acid medium [14]. Furlani et al. (2009) studied the use of carbohydrates, primarily lactose, as reducing agents for the leaching of manganese from the zinc alkaline battery powder [15]. The carbohydrates reduced $\mathrm{Mn}(\mathrm{IV})$ and $\mathrm{Mn}$ (III) oxides to acid-soluble $\mathrm{Mn}(\mathrm{II})$, and approximately twice the stoichiometric amount of lactose was used for complete leaching [15]. Gallegos et al. (2018) proposed a process using biogenerated sulfuric acid with 5 vol. $\% \mathrm{H}_{2} \mathrm{O}_{2}$ or $1 \mathrm{wt} . \% \mathrm{Na}_{2} \mathrm{SO}_{3}$ for the leaching of $\mathrm{Zn}$ and $\mathrm{Mn}$ in a single step [16]. In their study, $99 \%$ of $\mathrm{Zn}$ and $90-98 \%$ of Mn was extracted after $2 \mathrm{~h}$ of leaching at $30^{\circ} \mathrm{C}$ and $0.04 \mathrm{~g} / \mathrm{mL}$ [16]. Sodium metabisulfite $\left(\mathrm{Na}_{2} \mathrm{~S}_{2} \mathrm{O}_{5}\right)$ was also used as a reducing agent for the dissolution of metals from a mixture of spent batteries. In their research, Tanong et al. (2017) obtained 94 and $99 \%$ removal yields for $\mathrm{Mn}$ and $\mathrm{Zn}$, respectively, by adding $0.45 \mathrm{~g} \mathrm{Na}_{2} \mathrm{~S}_{2} \mathrm{O}_{5} / \mathrm{g}$ to battery powder in $\mathrm{H}_{2} \mathrm{SO}_{4} 1.34 \mathrm{M}$ in a single leaching step, with an $\mathrm{S} / \mathrm{L}$ ratio of $10.9 \%$ for $45 \mathrm{~min}$ at ambient temperature [6]. In other studies, a thermal pre-treatment was added to increase the efficacy of leaching. For example, Petranikova et al. (2018) investigated the effects of a thermal treatment at $300-950{ }^{\circ} \mathrm{C}$ of battery powder on the acid leaching $\left(0.5 \mathrm{M} \mathrm{H}_{2} \mathrm{SO}_{4}\right.$ at $25{ }^{\circ} \mathrm{C}$ for $\left.60 \mathrm{~min}\right)$ [17]. In general, these studies indicate that sulfuric acid leaching allows for the complete dissolving of $\mathrm{Zn}$ and partial extraction of $\mathrm{Mn}\left(\mathrm{MnO}, \mathrm{Mn}_{2} \mathrm{O}_{3}\right.$, 
and $\mathrm{Mn}_{3} \mathrm{O}_{4}$ ). The total dissolving of $\mathrm{Mn}$ (including $\mathrm{MnO}_{2}$ ) demands an auxiliary agent to reduce $\mathrm{MnO}_{2}$ to $\mathrm{MnO}$, soluble in sulfuric acid. Therefore, the leaching process can dissolve $\mathrm{Zn}$ and $\mathrm{Mn}$ simultaneously in a single step or via selective leaching in a two-step process. Selective leaching allows for the use of different techniques for recovery.

After leaching, the second challenge in the hydrometallurgical process is the efficient recovery of metals at high purities. The metals present in the leachate can be recovered by precipitation in the form of hydroxides, sulfides, or carbonates according to their respective $\mathrm{pH}$ and redox potential. Sobianowska-Turek et al. [18] used $\mathrm{NH}_{4} \mathrm{HCO}_{3} 3 \mathrm{M}$ and $\mathrm{NH}_{4} \mathrm{OH} 1 \mathrm{M}$ to recover almost $100 \%$ of manganese, iron, cadmium, and chromium, as well as $98.0 \%$ of cobalt, $95.5 \%$ of zinc, and $85.0 \%$ of copper and nickel from the solution after reductive acidic leaching $\left(\mathrm{H}_{2} \mathrm{SO}_{4}+\mathrm{C}_{2} \mathrm{H}_{2} \mathrm{O}_{4}\right)$ [18]. Furthermore, Sayilgan et al. used $\mathrm{KOH} 2 \mathrm{M}$ and $\mathrm{NaOH} 2 \mathrm{M}$ for the selective precipitation of manganese and zinc, with complete precipitation obtained for $\mathrm{Zn}$ at $\mathrm{pH} 7-8$ and $\mathrm{Mn}$ at $\mathrm{pH}$ 9-10 [19].

In industry, zinc is usually recovered in metallic form by electrowinning. In a study by Alfantazi and Dreisinger (2003), electrowinning experiments were conducted at an $80 \mathrm{~min}$ plating time, $500 \mathrm{~A} / \mathrm{m}^{2}$ current density, and temperature of $38^{\circ} \mathrm{C}$ with zinc-containing electrolyte zinc and $\mathrm{H}_{2} \mathrm{SO}_{4}$ concentrations of 62 and $170 \mathrm{~g} / \mathrm{L}$, respectively [20]. In this study, $90 \%$ of zinc was recovered by using an $\mathrm{Al}$ cathode and $\mathrm{Pb}$ anode. Similar results were recorded by Ivanov (2004) with an electrolyte containing 45-55 g Zn/L, 5-6 g Mn/L, and traces of other metals including, among others, Ni, Sb, and Ge [21].

In our study, in addition to developing an efficient battery recycling process, relevant economic factors were also considered. Economic factors generally include processing and operating costs, as well as transport and residue disposal costs. For example, Gasper et al. (2013) evaluated the economic viability for recycling alkaline batteries using mechanical separation [22]. Although the mechanical process developed in their study was cheaper than other reported processes (\$US529/ton), it was still not economically feasible, due to the low end-product value. The revenue of the end products was \$US 383/ton of batteries that consisted of brass, $\mathrm{Zn} / \mathrm{ZnO}$ powder, mixed Mn oxides powder, and $\mathrm{KOH}$ powder. In our study, we developed and described a complete hydrometallurgical process including the recovery of $\mathrm{Zn}$ by electrowinning and $\mathrm{Mn}$ by precipitation from alkaline battery powder. The process included dismantling, magnetic separation, leaching, and metal recovery. Furthermore, an economic evaluation was carried out to assess the feasibility on a global scale, especially for applications in Quebec (Canada), where an alkaline battery recycling process is not yet available.

\section{Materials and Methods}

\subsection{Process Description}

Figure 1 represents a flow sheet of the entire process for the recovery of $\mathrm{Zn}$ and $\mathrm{Mn}$ from spent alkaline batteries for this study. The globally relevant process includes two steps, namely, a physical pre-treatment step and a chemical treatment step. After dismantling, a representative sample of batteries is subjected to the attrition process followed by filtration and rinsing to remove any metallic powder attached to the coarse fraction. In addition to the separation of battery products, the removal of alkaline-soluble salts during this process reduces acid consumption in the following step. The coarse fraction is then transferred to the magnetic separator, allowing the magnetic fraction to be recycled as ferrous material and the non-magnetic fraction containing nylon, carton, and plastic to be used as energy sources. 


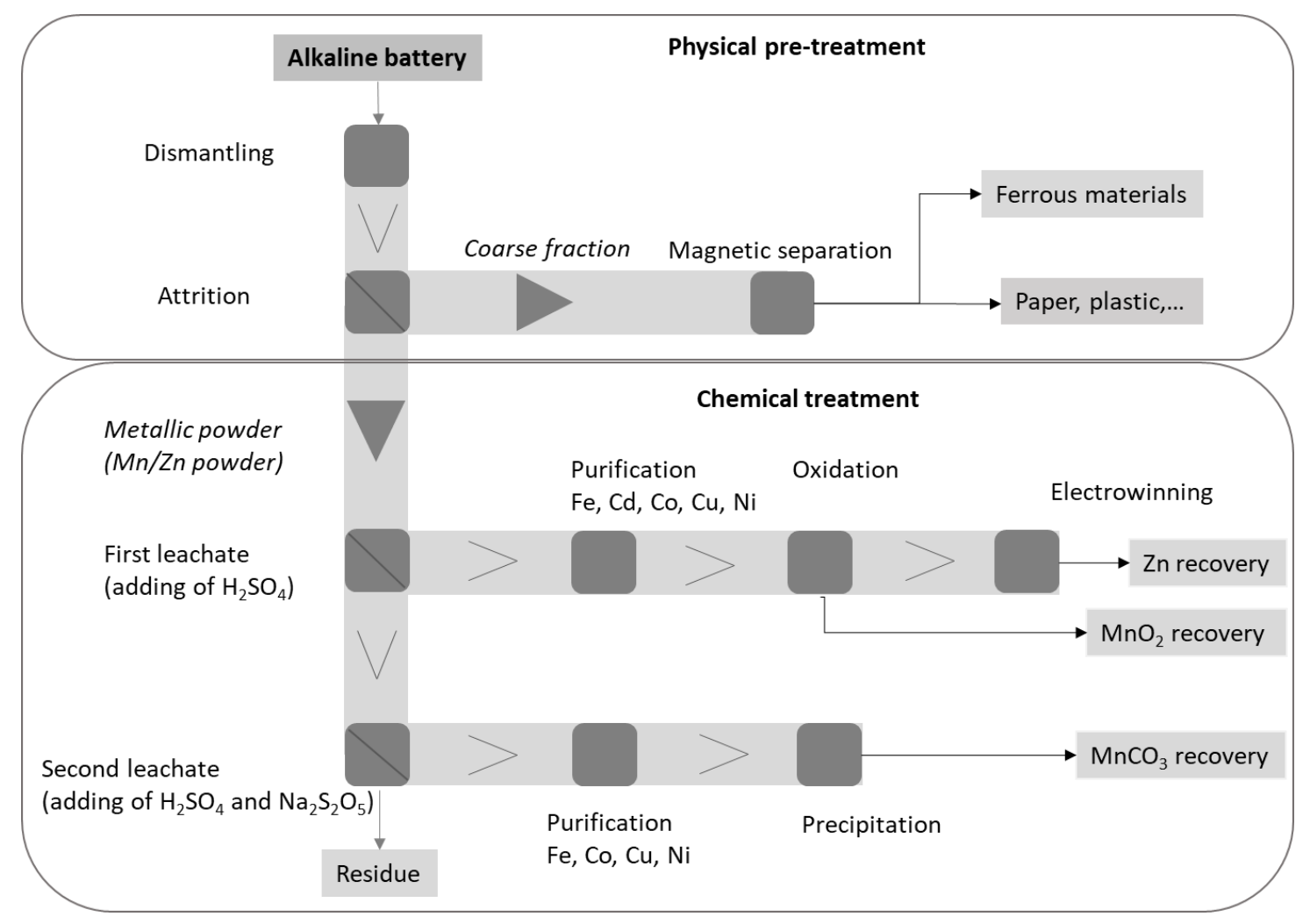

Figure 1. Detailed flow sheet of the hydrometallurgical route to treat the spent alkaline batteries.

The fine fraction containing manganese and zinc described as "metallic powder" is transferred to the chemical treatment, where zinc is dissolved during the first leaching step using sulfuric acid (Equation (1)). A portion of manganese, in the form of $\mathrm{MnO}, \mathrm{Mn}_{2} \mathrm{O}_{3}$, and $\mathrm{Mn}_{3} \mathrm{O}_{4}$, is also dissolved according to Equations (2) to (4) as follows:

$$
\begin{gathered}
\mathrm{ZnO}+\mathrm{H}_{2} \mathrm{SO}_{4} \rightarrow \mathrm{ZnSO}_{4} \\
\mathrm{MnO}+\mathrm{H}_{2} \mathrm{SO}_{4} \rightarrow \mathrm{MnSO}_{4}+\mathrm{H}_{2} \mathrm{O} \\
\mathrm{Mn}_{2} \mathrm{O}_{3}+\mathrm{H}_{2} \mathrm{SO}_{4} \rightarrow \mathrm{MnSO}_{4}+\mathrm{MnO}_{2}+\mathrm{H}_{2} \mathrm{O} \\
\mathrm{Mn}_{3} \mathrm{O}_{4}+2 \mathrm{H}_{2} \mathrm{SO}_{4} \rightarrow 2 \mathrm{MnSO}_{4}+\mathrm{MnO}_{2}+2 \mathrm{H}_{2} \mathrm{O}
\end{gathered}
$$

As $\mathrm{MnO}_{2}$ is insoluble in sulfuric acid, sodium metabisulfite $\left(\mathrm{Na}_{2} \mathrm{~S}_{2} \mathrm{O}_{5}\right)$ is added during the second leaching step to reduce $\mathrm{Mn}(\mathrm{IV})$ to $\mathrm{Mn}(\mathrm{II})$ [6]. During this leaching step, $\mathrm{MnO}_{2}$ in metallic powder is transferred in the leachate solution according to Equation (5):

$$
\mathrm{Na}_{2} \mathrm{~S}_{2} \mathrm{O}_{5}+2 \mathrm{MnO}_{2}+\mathrm{H}_{2} \mathrm{SO}_{4} \rightarrow 2 \mathrm{MnSO}_{4}+\mathrm{Na}_{2} \mathrm{SO}_{4}+\mathrm{H}_{2} \mathrm{O}
$$

After precipitation for the removal of iron, and cementation for the removal of trace metals such as $\mathrm{Ni}$ and $\mathrm{Cu}$, the first pregnant leach solution (PLS-1) is treated using sodium persulfate $\left(\mathrm{Na}_{2} \mathrm{~S}_{2} \mathrm{O}_{8}\right)$ to oxidize manganese for $\mathrm{MnO}_{2}$ recovery. Then, zinc is reduced by electrodeposition, resulting in a high-purity zinc metal. Furthermore, the second pregnant leach solution (PLS-2) is treated for the removal of iron and zinc followed by the precipitation of manganese as $\mathrm{MnCO}_{3}$. While the water used during this process can be reused through a counter-current mode, the final carbon-rich residue can be used for the fabrication of new batteries. 


\subsection{Physical Pre-Treatment}

\subsubsection{Sampling and Pre-Treatment}

The sample of spent alkaline $\mathrm{Zn}-\mathrm{MnO}_{2}$ and $\mathrm{Zn}-\mathrm{C}$ batteries was obtained from Laurentide Re-Sources Inc. (Victoriaville, QC, Canada). This company receives used batteries from various collection centers located throughout the Province of Quebec (Canada). During physical pre-treatment, spent alkaline batteries were shredded to approximately $1 \mathrm{~cm} \times 4 \mathrm{~cm}$ fractions using a mechanical grinder (Muffin Monster, model 30005, JWC Environmental ${ }^{\circledR}$, Santa Ana, CA, USA).

\subsubsection{Attrition Process}

The neutral attrition consisted of three 20 min steps with a solid/liquid (S/L) ratio fixed at 30\% $(w / w)$ and 700 rotations per minute (rpm). The high rotation speed accelerates the separation of fine powder from other parts of the battery including carton pieces, ferrous scraps, and plastic. This step is also useful in removing soluble potassium hydroxide from the battery powder. Attrition experiments were carried out using a $40 \mathrm{~L}$ stainless tank reactor equipped with three internal baffles. For each experiment, $3 \mathrm{~kg}$ of shredded battery material was combined with $10 \mathrm{~L}$ tap water for $20 \mathrm{~min}$ at ambient temperature. After each step, S/L separation was carried out using $1.7 \mathrm{~mm}$ sieves. The remaining coarser fraction was then rewashed until three attrition stages were complete. The metallic powder was removed from the liquid phase after $2 \mathrm{~h}$ of settling. The water used for the washing process was recycled via counter-current mode, the result will show the media after three cycles.

\subsection{Chemical Treatment}

\subsubsection{Leaching Process}

After washing, the metal powder was collected and different conditions were used to leach a maximum amount of zinc and manganese from the metallic powder. The challenge within this process is to obtain a high leaching efficiency and a PLS zinc concentration $\geq 40 \mathrm{~g} / \mathrm{L}$. This is important for avoiding energy loss during the electrowinning process. The selective leaching process was carried out in two stages in a $40 \mathrm{~L}$ stainless steel reactor. The water was recycled three times (LC 1 to 3 ) as presented in Figure 2. During the first cycle (LC 1), leaching was conducted with $4 \mathrm{~kg}$ of metallic powder in $2 \mathrm{M}$ $\mathrm{H}_{2} \mathrm{SO}_{4}$ and an $\mathrm{S} / \mathrm{L}$ ratio fixed at $40 \%(w / v)$ for $45 \mathrm{~min}$ at ambient temperature. For the second and third cycles (LC 2 and 3, respectively), leaching was conducted with $2 \mathrm{~kg}$ of metallic powder, and an S/L ratio of $20 \%$ in $1 \mathrm{M} \mathrm{H}_{2} \mathrm{SO}_{4}$, using the recycled solution after electrowinning (approximately 35-40 $\mathrm{g} \mathrm{Zn} / \mathrm{L}$ ).

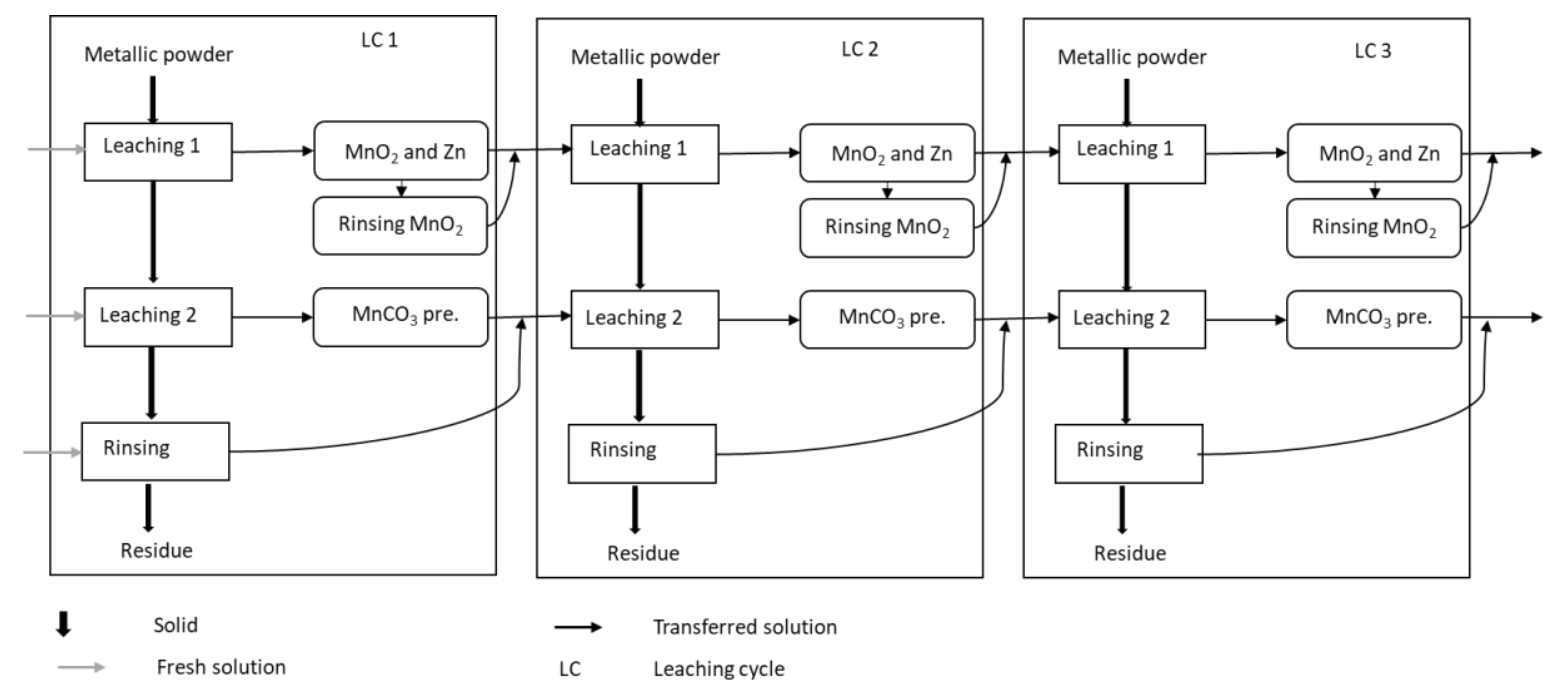

Figure 2. Schematic representation of the counter-current leaching and recovery process including rinsing steps performed on metallic powder. 
During the second leaching step, $0.45 \mathrm{~g} \mathrm{Na}_{2} \mathrm{~S}_{2} \mathrm{O}_{5}$ per gram of metallic powder was added to reduce $\mathrm{Mn}(\mathrm{IV})$ to $\mathrm{Mn}(\mathrm{II})$, soluble in $1.34 \mathrm{M} \mathrm{H}_{2} \mathrm{SO}_{4}$, with an $\mathrm{S} / \mathrm{L}$ ratio of $14 \%$ for 45 min at ambient temperature. The PLS-2 obtained from the second leaching step contained a significant proportion of manganese. Following each leaching step, S/L separation was carried out by filtration.

\subsubsection{Purification}

Both PLS-1 and PLS-2 were purified prior to zinc and manganese recovery. The iron removal from PLS-1 was carried out at $\mathrm{pH} 4.0-4.5$ by the addition of sodium hydroxide $(\mathrm{NaOH})$ and hydrogen peroxide $\left(\mathrm{H}_{2} \mathrm{O}_{2}\right)$. The added $\mathrm{H}_{2} \mathrm{O}_{2}$ dose was 1.5 times that of the stoichiometric molar ratio (SMR) of the total iron concentration (approximately $2 \mathrm{mM}$ for PLS-1 and $30 \mathrm{mM}$ for PLS-2).

After iron removal, the solution was purified by cementation using $\mathrm{Zn}$ powder to remove metal traces, such as $\mathrm{Ni}, \mathrm{Cu}$, and $\mathrm{Co}$ via the following equation:

$$
\mathrm{Zn}_{(\mathrm{s})}+\mathrm{M}^{2+}{ }_{(\mathrm{aq})} \rightarrow \mathrm{Zn}^{2+}{ }_{(\mathrm{aq})}+\mathrm{M}_{(\mathrm{s})}
$$

where $\mathrm{M}$ represents metal traces such as $\mathrm{Ni}, \mathrm{Cu}$, and $\mathrm{Co}$.

In our study, a quantity of $\mathrm{Zn}$ metal powder equal to 20 times the impurity of metals (around $200 \mathrm{mg} / \mathrm{L}$ ) was added, and cementation was conducted at $80^{\circ} \mathrm{C}$ at $\mathrm{pH} 4.0-4.5$ for 30-120 min.

Using the same principle, iron was also removed from PLS-2. Thereafter, the $\mathrm{Zn}$ residual (about $0.1 \mathrm{~mol} / \mathrm{L})$ in the PLS-2 was precipitated out using sodium sulfide $\left(\mathrm{Na}_{2} \mathrm{~S}\right)$ at $\mathrm{pH}$ 4.0-5.0. The SMR values of 1,2, and 3 were used during these experiments. The $\mathrm{ZnS}$ precipitate was then returned to the first leaching step and the PLS-2 was transferred to the $\mathrm{MnCO}_{3}$ recovery step.

\subsubsection{Metal Recovery from PLS-1}

Oxidation- $\mathrm{MnO}_{2}$ Recovery

The recovery of $\mathrm{MnO}_{2}$ was performed by manganese oxidation using sodium persulfate $\left(\mathrm{Na}_{2} \mathrm{~S}_{2} \mathrm{O}_{8}\right)$ according the following equation:

$$
\mathrm{MnSO}_{4}+\mathrm{Na}_{2} \mathrm{~S}_{2} \mathrm{O}_{8}+2 \mathrm{H}_{2} \mathrm{O} \rightarrow \mathrm{MnO}_{2}+\mathrm{Na}_{2} \mathrm{SO}_{4}+2 \mathrm{H}_{2} \mathrm{SO}_{4}
$$

The purified solution of $\mathrm{ZnSO}_{4}$ and $\mathrm{MnSO}_{4}$ from the previous step was used to recover $\mathrm{MnO}_{2}$. The kinetic reaction was carried out with $1 \mathrm{SMR} \mathrm{Na}_{2} \mathrm{~S}_{2} \mathrm{O}_{8}$ at $60^{\circ} \mathrm{C}$ (nearby $0.6 \mathrm{M}$ of $\mathrm{Mn}$ ), and the $\mathrm{pH}$ increased in the range of $2-4$ by adding $\mathrm{NaOH}$. The $\mathrm{S} / \mathrm{L}$ separation was carried out by filtration and the resulting liquid was transferred to the next step for $\mathrm{Zn}$ recovery. The $\mathrm{MnO}_{2}$ precipitate was washed with an S/L ratio of $10 \%$ for $10 \mathrm{~min}$ (200 rpm) to obtain high-purity $\mathrm{MnO}_{2}$.

Electrowinning-Zn Recovery

An acrylic reactor, $8.5 \mathrm{~cm}$ (width) $\times 70 \mathrm{~cm}$ (length) $\times 15 \mathrm{~cm}$ (depth), was used for electrodeposition experiments. The electrode sets consisted of 14 aluminum cathodes and $15 \mathrm{~Pb} / \mathrm{Ag}$ anodes, each with a surface area of $119 \mathrm{~cm}^{2}(4.5 \mathrm{~cm}$ (width) $\times 10 \mathrm{~cm}$ (height) $\times 1 \mathrm{~cm}$ (thickness)). Electrodes were placed in parallel, $1 \mathrm{~cm}$ apart. The cathodes and anodes were connected to the negative and positive outlets of a DC power supply, respectively, Xantrex XFR (ACA TMetrix, Mississauga, ON, Canada). The working volume was fixed to $5 \mathrm{~L}$ at ambient temperature for all electrowinning experiments. Assays were conducted in batch mode with continuous mixing using a water recirculation system in the reactor. The purified solution of $\mathrm{ZnSO}_{4}(\mathrm{pH}=2)$ after $\mathrm{MnO}_{2}$ precipitate recovery was used in the electrowinning experiments, in which $\mathrm{Zn}$ was deposited on the cathode surface with a current density between 250 and $750 \mathrm{~A} / \mathrm{m}^{2}$ and an electrowinning time of $180 \mathrm{~min}$. In this condition, the potential was dropped from 5.6 to $5.2 \mathrm{~V}$. Samples of electrolyte were taken after 15, 30, 45, 60, 90, and $180 \mathrm{~min}$ to analyze the residual metal concentration. 


\subsubsection{Metal Recovery from PLS-2: $\mathrm{MnCO}_{3}$ Precipitation}

Sodium carbonate $\left(\mathrm{Na}_{2} \mathrm{CO}_{3}\right)$ was used to precipitate manganese from PLS-2 (a quantity of $90 \mathrm{~g}$ $\mathrm{Na}_{2} \mathrm{CO}_{3}$ was added for $1 \mathrm{~L}$ of PLS-2). The $\mathrm{MnCO}_{3}$ precipitate was rinsed using an S/L ratio of $10 \%$ for $10 \mathrm{~min}$ for a moderate-speed mixing (200 rpm) to eliminate dissolved sulfur and sodium from the $\mathrm{MnCO}_{3}$ powder after precipitation. All precipitation experiments were carried out at ambient temperature.

\subsection{Analytical Methods}

Liquid samples were filtered using G6 glass fiber paper (Fisher brand, Fisher Scientific, Ottawa, $\mathrm{ON}$, Canada, pore size $=1.5 \mu \mathrm{m}$ ) to remove solid particles, and stored in $5 \% \mathrm{HNO}_{3}$ before analysis. Solid samples were dissolved with nitric and hydrochloric acid $\left(\mathrm{HNO}_{3}\right.$ and $\mathrm{HCl}$, respectively) before analysis. Metal mobility in the final residual (after the second leaching step) was evaluated using the toxicity characteristic leaching procedure (TCLP)—Method 1311. The metal concentrations in all samples were determined using an inductively coupled plasma-optical emission spectrometer (ICP-OES) (model 725-ES, Agilent Technologies, Santa Clara, CA, USA).

\subsection{Techno-Economic Evaluation of the Hydrometallurgical Process}

The economic simulation for a battery recycling plant required a large number of parameters (variables) in order to estimate the economic performance of the process. For this study, a computer model was developed to evaluate both direct and indirect costs of the proposed recycling process. This model included more than 260 input variables to define, among others, the various processing steps, capitalization, and operating parameters. The techno-economic analysis was based on parameters and efficiency values obtained from pilot-scale experiments, but increased to a basis of 2800 tons of batteries processed per year $\left(t \cdot y^{-1}\right)$. This capacity represents the actual amount of batteries collected in Canada. Therefore, the capacity plant was developed for 8 tons per day $\left(\mathrm{t} \cdot \mathrm{d}^{-1}\right)$, with a running time of $8 \mathrm{~h}$ per day, and annual operation of $350 \mathrm{~d} \cdot \mathrm{y}^{-1}$. Once the capacity of the plant was established, it was possible to adjust the dimensions of the required equipment, according to the specific process. The total cost was established based on variable equations including dimensions and capacity of equipment, purchase costs and transport of equipment, electric and thermal requirements, as well as energy consumption, as recorded in previous studies [23]. Depreciation and annual interest charges were estimated using a 20-year equipment lifetime, as well as a working capital of $15 \%$ of fixed capital costs. In addition, used market parameters were defined as follows: An inflation rate of $2 \%$, an annual interest rate of $5 \%$, and an annual discount rate of $6 \%$. Table 2 presents the basic operating parameters taken from the Canadian market and relevant literature [23-25].

Table 2. Basic operating parameters, market parameters, and capitalization parameters of the techno-economic model for recycling spent alkaline batteries.

\begin{tabular}{ccc}
\hline Parameters & Values & Units \\
\hline Basic operating parameters & - & - \\
Operating period & 350 & $\mathrm{~d} / \mathrm{yr}$ \\
Processing capacity of a plant & 8 & $\mathrm{t} / \mathrm{d}$ \\
Daily operation period & 8 & $\mathrm{~h} / \mathrm{d}$ \\
Factor of safety (for equipment) & 20 & $\%$ \\
\hline Market parameters & - & - \\
Annual inflation rate & 2.0 & $\% / \mathrm{yr}$ \\
Annual interest rate & 5.0 & $\% / \mathrm{yr}$ \\
Annual discount rate & 6.0 & $\%$ of gross income \\
Income tax & 30 & $\$ \mathrm{US} / \$ \mathrm{AD}$ \\
Exchange rate & 1.25 & $\mathrm{dec}-18$ \\
\hline
\end{tabular}


Table 2. Cont.

\begin{tabular}{ccc}
\hline Parameters & Values & Units \\
\hline Capitalization parameters & - & - \\
Amortization period & 20 & yr \\
Lifetime of equipment & 20 & yr \\
\hline Direct (dir.) costs & - & - \\
Equipment & - & - \\
Insulation installation equipment & 19 & $\%$ \\
Instrumentation and control & 3 & $\%$ \\
Piping and pipeline systems & 7 & $\%$ \\
Electrical system & 8 & $\%$ \\
Building process and services & 18 & $\%$ \\
Landscaping & 3 & $\%$ \\
Facilities and services & 14 & - \\
Indirect (indir.) costs & - & $\%$ \\
Engineering and supervision & 32 & $\%$ \\
Construction spending & 10 & $\%$ cap. (dir. + indir.) \\
Construction management fees & 9 & $\%$ fixed capital costs \\
Contingent fees & 26 & indir.) \\
Working capital & 15 & $\%$
\end{tabular}

\section{Results and Discussion}

\subsection{Mass Balance for Physical Pre-Treatment}

After three stages of attrition, samples were divided into the following two parts: Coarse fraction (larger than $1.7 \mathrm{~mm}$ ) and fine fraction (smaller than $1.7 \mathrm{~mm}$ ). The coarse fraction consisted of a ferrous fraction $(22 \%)$ and non-ferrous fraction $(4 \%)$, while the fine fraction contained graphite carbon with metallic powder. Water used for the initial washing contained soluble electrolytes, primarily $\mathrm{KOH}$ (4\%). According to our results, $1924 \mathrm{~g}$ of metallic powder (68\% of total mass) was recovered from $2833 \mathrm{~g}$ of battery waste with a mass balance of $98.9 \%$. During attrition with water, the $\mathrm{pH}$ decreased slightly to 12.8 (stage 1), 11.4 (stage 2), and 10.3 (stage 3).

Table 3 presents the average composition of batteries after physical pre-treatment with recirculated water. This distribution corresponds to results from an investigation on the composition of spent AA alkaline batteries by Almeida et al. [26]. Findings from their study reported alkaline batteries to consist of $2.9 \%$ plastic and paper, which is equivalent to the non-ferrous fraction of our study; $21.8 \%$ metal and brass, which is equivalent to the ferrous fraction; and $75.3 \%$ anode and cathode, which is equivalent to $\mathrm{KOH}$ and metallic powder. Although slight differences may be attributed to the sampling method and technical separation, these results indicate the high efficacy of washing for obtaining metallic powder.

Table 3. Composition of the battery after separation by attrition and magnetic separation (physical pre-treatment).

\begin{tabular}{cccc}
\hline Characteristics & Fraction & Mass $(\mathrm{g})$ & Proportion (\%) \\
\hline Initial & & $2833 \pm 29$ & \\
& Ferrous fraction & $639 \pm 16$ & $22.4 \pm 0.6$ \\
$>1.7 \mathrm{~mm}$ fraction & Non-ferrous fraction & $124 \pm 12$ & $4.4 \pm 0.4$ \\
& Metallic powder & $1924 \pm 16$ & $67.5 \pm 0.6$ \\
\multirow{2}{*}{ (1.7 mm fraction } & Soluble fraction $(\mathrm{KOH}, \ldots)$ & $115 \pm 6$ & $4.0 \pm 0.2$ \\
\hline
\end{tabular}

The chemical composition of the resulting metallic powder from the attrition process is shown in Table 4. The quantities of zinc and manganese are 240 and $326 \mathrm{~g}$ per $\mathrm{kg}$ of metallic powder, respectively. The high concentration of potassium $(25.5 \mathrm{~g} / \mathrm{kg})$ is associated with the high quantity of alkaline 
batteries in comparison to $\mathrm{Zn}-\mathrm{C}$ batteries in the original sample. The collected metal powder was then transferred to the acid leaching process.

Table 4. Chemical composition of metallic powder.

\begin{tabular}{ccccccc}
\hline Elements & Na & Fe & Mn & Zn & K & Other \\
\hline Concentration $(\mathrm{g} / \mathrm{kg})$ & 0.10 & 14.5 & 326 & 240 & 25.5 & 0.96 \\
\hline
\end{tabular}

\subsection{Selective Leaching of $\mathrm{Zn}$ and $\mathrm{Mn}$}

\subsubsection{PLS-1 Leachate}

Several groups of researchers have studied the extraction of metals from battery powder using sulfuric acid. In our study, during the first leaching process, metallic powder was leached in $2 \mathrm{M}$ $\mathrm{H}_{2} \mathrm{SO}_{4}$ with $\mathrm{S} / \mathrm{L}$ ratios of $10,20,40$, and $50 \%$ for $90 \mathrm{~min}$ at ambient temperature. Our results indicate that the leaching efficiency of $\mathrm{Zn}$ was related to the amount of total solids and reaction time (Figure 3).

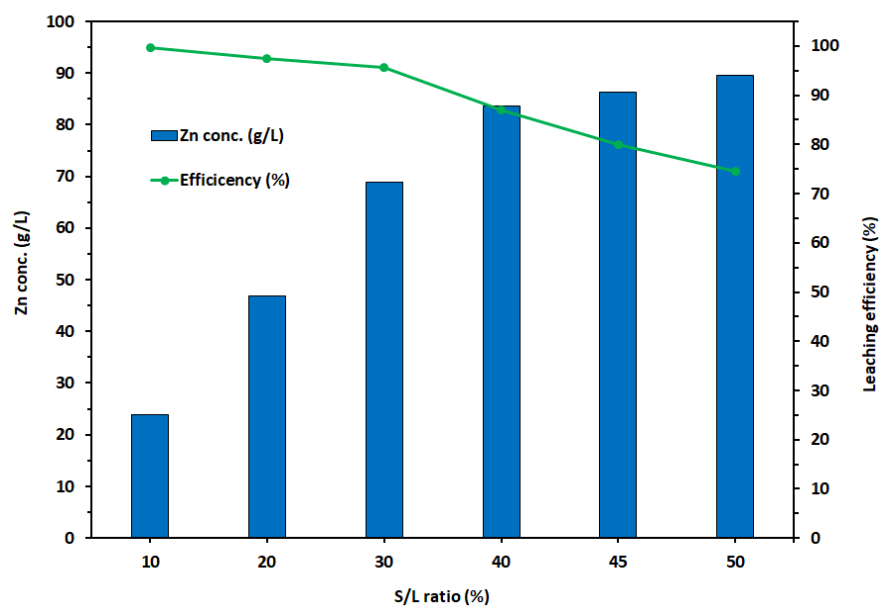

Figure 3. Variation in Zn concentration and the first leaching efficiency (\%) with different solid/liquid $(\mathrm{S} / \mathrm{L})$ ratios.

The results indicate that an increase in S/L ratio increased leaching up to $90 \mathrm{~g} \mathrm{Zn/L.} \mathrm{Nevertheless,}$ an increase in the S/L ratio also decreased the leaching efficiency. The concentration of $\mathrm{Zn}$ in the effluent is an important parameter for electrowinning in this process, and, therefore, an S/L ratio of $40 \%$ was chosen for the first cycle of leaching and $20 \%$ for the next cycles. A $40 \%(w / v)$ ratio allowed for the dissolving of $87.1 \%$ of $\mathrm{Zn}$ with a concentration of $83.6 \mathrm{~g} / \mathrm{L}$, after $45 \mathrm{~min}$ (Table 5). Under these conditions, the concentration of Mn in PLS-1 was $28.5 \mathrm{~g} / \mathrm{L} \mathrm{(22 \%} \mathrm{of} \mathrm{Mn} \mathrm{in} \mathrm{the} \mathrm{battery} \mathrm{powder).}$

Table 5. Composition of metals in different solutions (pregnant leach solution 1 (PLS-1): $2 \mathrm{M} \mathrm{H}_{2} \mathrm{SO}_{4}$, $\mathrm{S} / \mathrm{L}$ ratio of $40 \%$ and PLS-2: $1.34 \mathrm{M} \mathrm{H}_{2} \mathrm{SO}_{4}, \mathrm{~S} / \mathrm{L}$ ratio of $14.1 \%, 0.45 \mathrm{~g} \mathrm{Na}_{2} \mathrm{~S}_{2} \mathrm{O}_{5} / \mathrm{g}$ metallic powder for $45 \mathrm{~min})$.

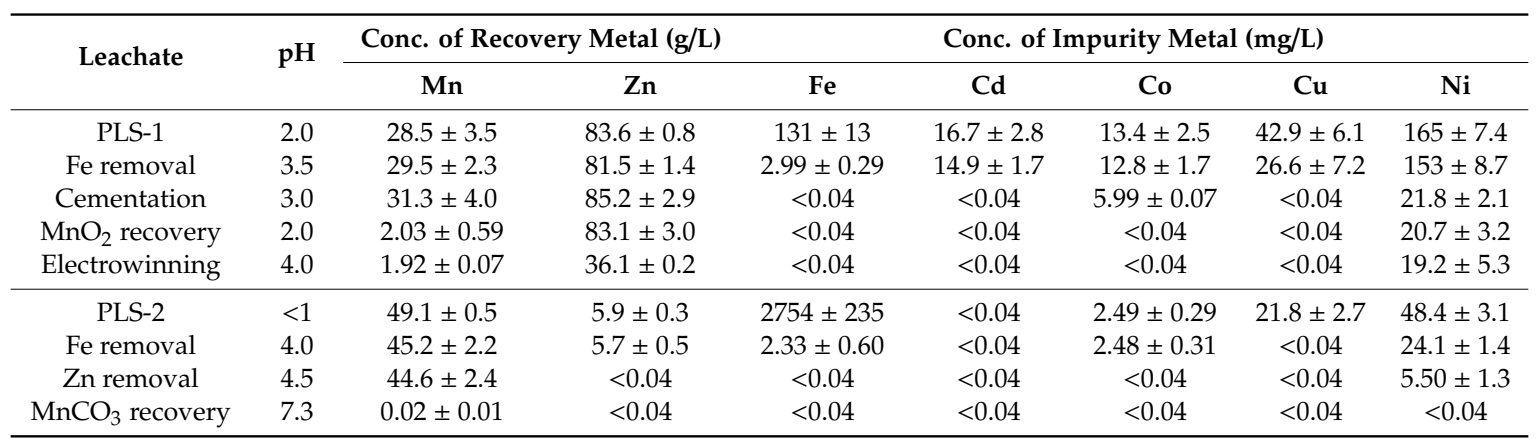




\subsubsection{PLS-2 Leachate}

Notably, the weight of solids was reduced after the first leaching by the dissolving of metals in PLS-1, with the mass of metal powder decreasing from 400 to $284 \mathrm{~g}$ after the first leaching. The addition of $\mathrm{Na}_{2} \mathrm{~S}_{2} \mathrm{O}_{5}\left(0.45 \mathrm{~g} \mathrm{Na}_{2} \mathrm{~S}_{2} \mathrm{O}_{5}\right.$ for $1 \mathrm{~g}$ metallic powder) in the second leaching resulted in more than $96 \%$ of $\mathrm{Mn}$ being dissolved. The $\mathrm{S} / \mathrm{L}$ ratio had a negative impact on the leaching of $\mathrm{Mn}$ with a decrease in the $\mathrm{S} / \mathrm{L}$ ratio from 35 to $9 \%$, resulting in an increase in Mn extraction rate from 72 to $96 \%$. The $\mathrm{S} / \mathrm{L}$ ratio of $14.1 \%$ made it possible to extract $96.5 \%$ of $\mathrm{Mn}(49.1 \mathrm{~g} / \mathrm{L})$. Under these conditions, the concentration of $\mathrm{Zn}$ in PLS-2 was $5.87 \mathrm{~g} / \mathrm{L}$ (a $94.5 \%$ solubilization of $\mathrm{Zn}$ ). Table 5 represents the classification of PLS-1 and PLS-2. Our results confirm the important role of $\mathrm{Na}_{2} \mathrm{~S}_{2} \mathrm{O}_{5}$ as the reducing agent for dissolving $\mathrm{Mn}$ in the leachate (PLS-2). In an $\mathrm{H}_{2} \mathrm{SO}_{4}$ solution, the leaching yield of $\mathrm{Mn}$ increased from 22 to $96.5 \%$ with the addition of $\mathrm{Na}_{2} \mathrm{~S}_{2} \mathrm{O}_{5}$. The residue mass decreased from 284 to $140 \mathrm{~g}$ after the second leaching.

Table 6 represents the mass distribution for the leaching process for $1 \mathrm{~kg}$ of metallic powder and also the global efficiency of the leaching process. The composition of metals (in $\mathrm{mg} / \mathrm{kg}$ of residue) in residue is also represented in Table 6. The combination of $\mathrm{Na}_{2} \mathrm{~S}_{2} \mathrm{O}_{5}$ with sulfuric acid led to the dissolving of not only $\mathrm{Zn}$ and $\mathrm{Mn}$, but also other metals ( $\mathrm{Co}, \mathrm{Cu}, \mathrm{Ni})$ of more than $98.4 \%$.

Table 6. Composition of metals in different fractions for each step of leaching.

\begin{tabular}{cccccccc}
\hline Samples & Mn & Zn & Fe & Cd & Co & Cu & Ni \\
\hline Metallic powder (g) & 326 & 240 & 14.5 & 0.041 & 0.045 & 0.22 & 0.65 \\
PLS-1 (g) & $71.3 \pm 8.8$ & $209 \pm 2$ & $0.33 \pm 0.03$ & $0.042 \pm 0.007$ & $0.034 \pm 0.006$ & $0.11 \pm 0.02$ & $0.41 \pm 0.02$ \\
PLS-2 (g) & $246 \pm 3$ & $29.4 \pm 1.6$ & $13.8 \pm 1.2$ & $<0.0002$ & $0.013 \pm 0.002$ & $0.11 \pm 0.01$ & $0.24 \pm 0.02$ \\
Leaching 1 efficiency (\%) & $21.9 \pm 2.7$ & $87.0 \pm 0.8$ & $2.3 \pm 0.2$ & $101 \pm 17$ & $74.3 \pm 14.1$ & $48.8 \pm 6.9$ & $63.3 \pm 2.8$ \\
Global leaching efficiency (\%) & $97.2 \pm 2.6$ & $99.3 \pm 1.0$ & $97.2 \pm 8.3$ & $101 \pm 17$ & $102 \pm 14$ & $98.4 \pm 0.9$ & $101 \pm 1.5$ \\
Residue (mg/kg) & $26.7 \pm 2.4$ & $6.8 \pm 1.2$ & $4.2 \pm 0.5$ & $5.6 \pm 3.2$ & $3.2 \pm 1.2$ & $20.5 \pm 6.9$ & $110 \pm 24$ \\
\hline
\end{tabular}

\subsubsection{Final Residue}

A TCLP test was conducted on the final residue in order to validate the effectiveness of the leaching process and residue valorization capacity. Table 7 presents the TCLP results for the residue obtained in our study across three cycles with the recycling of water. All results were below USEPA limits for the potential hazards of waste [27]. The residue obtained after the second leaching is not considered hazardous and could, therefore, be used for other applications, such as a material for the production of batteries.

Table 7. Metal concentration in leachate by toxicity characteristic leaching procedure (TCLP) for final residue.

\begin{tabular}{ccccc}
\hline \multirow{2}{*}{ Elements } & US EPA $(\mathbf{m g} / \mathbf{L})$ & \multicolumn{3}{c}{ Residue From } \\
\cline { 3 - 5 } & & LC1 & LC2 & LC3 \\
\hline $\mathrm{As}$ & 5.0 & $<0.01$ & $<0.01$ & $<0.01$ \\
$\mathrm{Ba}$ & 100 & 0.11 & 0.19 & 0.12 \\
$\mathrm{Cd}$ & 1.0 & 0.22 & 0.14 & 0.47 \\
$\mathrm{Cr}$ & 5.0 & $<0.0006$ & $<0.0006$ & 0.01 \\
$\mathrm{~Pb}$ & 5.0 & $<0.005$ & $<0.005$ & $<0.005$ \\
$\mathrm{Hg}$ & 0.2 & 0.05 & 0.01 & 0.003 \\
$\mathrm{Se}$ & 1.0 & 0.02 & 0.05 & 0.03 \\
$\mathrm{Ag}$ & 5.0 & 5.2 & $<0.01$ & $<0.01$ \\
$\mathrm{Ni}$ & 250 & 1.8 & 3.7 & 6.9 \\
$\mathrm{Cu}$ & 250 & & 0.56 & 0.19 \\
\hline
\end{tabular}




\subsection{Purification and Recovery of Metals}

\subsubsection{Recovery of $\mathrm{MnO}_{2}$ from PLS-1 Solution}

Purification

Iron precipitation tests were carried out under the same conditions as those used in a study by Blais et al. (2016) with 1.5 times SMR of $\mathrm{H}_{2} \mathrm{O}_{2}$ for oxidizing $\mathrm{Fe}^{2+}$ ions to $\mathrm{Fe}^{3+}$ at $\mathrm{pH}=4, \mathrm{~T}=25^{\circ} \mathrm{C}$, and stirring rate $=200 \mathrm{rpm}$ [28]. Under these conditions, $98 \%$ of Fe in the PLS-1 was precipitated. A concentration of $131 \mathrm{mg}$ Fe/L was recorded in the PLS-1 and a $2.99 \mathrm{mg}$ Fe/L was measured after Fe removal (Table 5). In this step, the concentration of $\mathrm{Cu}$ decreased from 42.9 to $26.6 \mathrm{mg} / \mathrm{L}$. After iron removal, cementation was used to remove impurities such as $\mathrm{Cd}, \mathrm{Co}$, and $\mathrm{Ni}$. The impurities more electropositive than $\mathrm{Zn}$ could be removed by adding metal $\mathrm{Zn}$ powder and controlling the $\mathrm{pH}$ and temperature of the solution [29]. The most efficient removal of $\mathrm{Cd}(100 \%), \mathrm{Co}(53 \%), \mathrm{Cu}(100 \%)$, and Ni $(86 \%)$ was obtained after $120 \mathrm{~min}$. The low rate of Co removal in our study corresponds to observations made in other studies [29,30]. Furthermore, these studies also mention the difficulty of removing Co due to the small potential difference between $\mathrm{Zn}$ and $\mathrm{Co}-\mathrm{Zn}$ alloys. In addition, the low concentration of cobalt $(13.4 \mathrm{mg} / \mathrm{L})$ also makes it more difficult to remove. Notably, $\mathrm{Cd}$ and $\mathrm{Cu}$ can be removed at lower temperatures $\left(25-40{ }^{\circ} \mathrm{C}\right)$ and at a $\mathrm{pH}$ between 2.0 and 2.5. However, a temperature of $80^{\circ} \mathrm{C}$ and a $\mathrm{pH}$ of $4-5$ are necessary for the cementation of $\mathrm{Ni}$ [30]. The slight increase in $\mathrm{Mn}$ (from 28.5 to $31.3 \mathrm{mg} / \mathrm{L})$ and $\mathrm{Zn}(83.6$ to $85.2 \mathrm{mg} / \mathrm{L})$ concentration can be explained by the evaporation of water during the cementation process at $80^{\circ} \mathrm{C}$.

Precipitation of $\mathrm{MnO}_{2}$

Across all experiments, 1 SMR of $\mathrm{Na}_{2} \mathrm{~S}_{2} \mathrm{O}_{8}$ was used for the oxidation of $\mathrm{Mn}^{2+}$ to $\mathrm{MnO}_{2}$. As suggested by Demopoulos et al. (2002), this reaction was performed at $60{ }^{\circ} \mathrm{C}$ and at a controlled $\mathrm{pH}$ to investigate the oxidation kinetics of $\mathrm{Mn}^{2+}$ ions in $\mathrm{MnO}_{2}$ at a $\mathrm{pH}$ between 2 and 4 [31].

The residual concentration of $\mathrm{Mn}$ at $\mathrm{pH} 2, \mathrm{pH} 3$, and $\mathrm{pH} 4$ was investigated. According to our results, the oxidation at $\mathrm{pH}=3$ gave a good oxidation yield (93\%). After $120 \mathrm{~min}, \mathrm{Mn}$ concentration in the solution decreased from 31.3 to $2.03 \mathrm{~g} / \mathrm{L}$ (Table 8). An amount of $2 \mathrm{~g} \mathrm{Mn} / \mathrm{L}$ in the solution had a positive effect on the next step of Zn electro-deposition [32]. Notably, traces of Co co-precipitated with $\mathrm{MnO}_{2}$, whereas Ni did not precipitate with $\mathrm{MnO}_{2}$ (Table 8).

Table 8. Oxidation kinetics of $\mathrm{Mn}^{2+}$ to $\mathrm{MnO}_{2}$ in different $\mathrm{pHs}$.

\begin{tabular}{cccccc}
\hline \multirow{2}{*}{$\mathbf{p H}$} & \multirow{2}{*}{ Temps. (min) } & \multicolumn{2}{c}{ Conc. (g/L) } & \multicolumn{2}{c}{ Conc. (mg/L) } \\
\cline { 2 - 6 } & & $\mathbf{M n}$ & $\mathbf{Z n}$ & $\mathbf{C o}$ & $\mathbf{N i}$ \\
\cline { 2 - 6 } & Initial & 31.3 & 85.2 & 5.99 & 21.8 \\
\hline \multirow{2}{*}{2} & 15 & 22 & 85.2 & 5.87 & 21.9 \\
& 30 & 19 & 84.9 & 5.95 & 21.8 \\
& 60 & 14 & 84.9 & 4.02 & 21.7 \\
& 120 & 5 & 83.9 & 3.09 & 21.9 \\
3 & 15 & 18 & 84.2 & 5.13 & 21.6 \\
& 30 & 16 & 84.1 & 4.38 & 21.9 \\
& 60 & 8 & 83.6 & 2.01 & 21.1 \\
& 120 & 2.03 & 83.1 & ND & 20.7 \\
\hline \multirow{3}{*}{4} & 15 & 31.3 & 84.2 & 4.35 & 21.2 \\
& 30 & 24.1 & 83.7 & ND & 19.4 \\
& 60 & 3.01 & 82.5 & ND & 15.2 \\
& 120 & ND & 79.3 & ND & 15.1 \\
\hline
\end{tabular}




\subsubsection{Electrowinning for Recovery of Zn Metal from PLS-1 Solution}

The effect of current density on the electrowinning of $\mathrm{Zn}$ was evaluated by measuring the residual concentration of $\mathrm{Zn}$ between 250 and $750 \mathrm{~A} / \mathrm{m}^{2}$ for $180 \mathrm{~min}$. The results clearly indicate that the deposition efficiency of $\mathrm{Zn}$ increased with an increase in current density. The high concentration of $\mathrm{Mn}$ $(>5 \mathrm{~g} / \mathrm{L})$ in the solution decreased the faradic yield [32], while a lower concentration (between 1 and $5 \mathrm{~g} / \mathrm{L}$ ) had a positive effect on oxidation, thereby protecting the electrodes and increasing the purity of the deposited $\mathrm{Zn}$ [32]. At a high current density $\left(750 \mathrm{~A} / \mathrm{m}^{2}\right)$, a decrease in Mn concentration was observed (from 2.03 to $0.22 \mathrm{~g} / \mathrm{L}$ ), which is consistent with the results obtained by Poinsignon et al. [33], where $\mathrm{Mn}$ oxidized at the anode and precipitated as $\mathrm{MnO}_{2}$. The largest $\mathrm{Zn}$ deposit was obtained with a current density of $500 \mathrm{~A} / \mathrm{m}^{2}$. Under these conditions, Mn concentration remained stable (from 2.03 to $1.92 \mathrm{~g} / \mathrm{L})$.

Figure 4 shows the changes in $\mathrm{Zn}$ deposition as a function of time at a current density of $500 \mathrm{~mA} / \mathrm{m}^{2}$. In the figure, two different zones can be distinguished, with the yield of Zn deposits increasing linearly with time until $90 \mathrm{~min}$. After $90 \mathrm{~min}$, the rate of Zn deposits decreased significantly. Notably, at the start of the electrowinning process, Zn concentration was relatively high $(83.1 \mathrm{~g} / \mathrm{L})$ and, accordingly, the $\mathrm{Zn}$ deposit rate was subjected to current control. As the $\mathrm{Zn}$ deposit achieved a certain thickness and the $\mathrm{Zn}$ concentration was below a certain level (approximately $40 \mathrm{~g} / \mathrm{L}$ ), we conclude that the $\mathrm{Zn}$ deposit rate is limited by mass transfer control. This explains why the $\mathrm{Zn}$ deposit rate remained constant with time. Figure 4 also presents the change in energy consumption as a function of time, indicating that energy consumption increased linearly to $156 \mathrm{kWh} / \mathrm{m}^{3}$ after $180 \mathrm{~min}$. It has been established that $\mathrm{Zn}$ deposition efficiency is affected by reaction time and the cost of the electrowinning process. In view of reducing power use and increasing $\mathrm{Zn}$ deposits, a time of $90 \mathrm{~min}$ was selected for the process. Under these conditions, the residual concentration of $\mathrm{Zn}$ in the solution was $36.1 \mathrm{~g} / \mathrm{L}$. The solution was also recirculating for the first leaching (S/L ratio of $40 \%$ ) and, consequently, an S/L ratio of $20 \%$ was used for the second cycle.

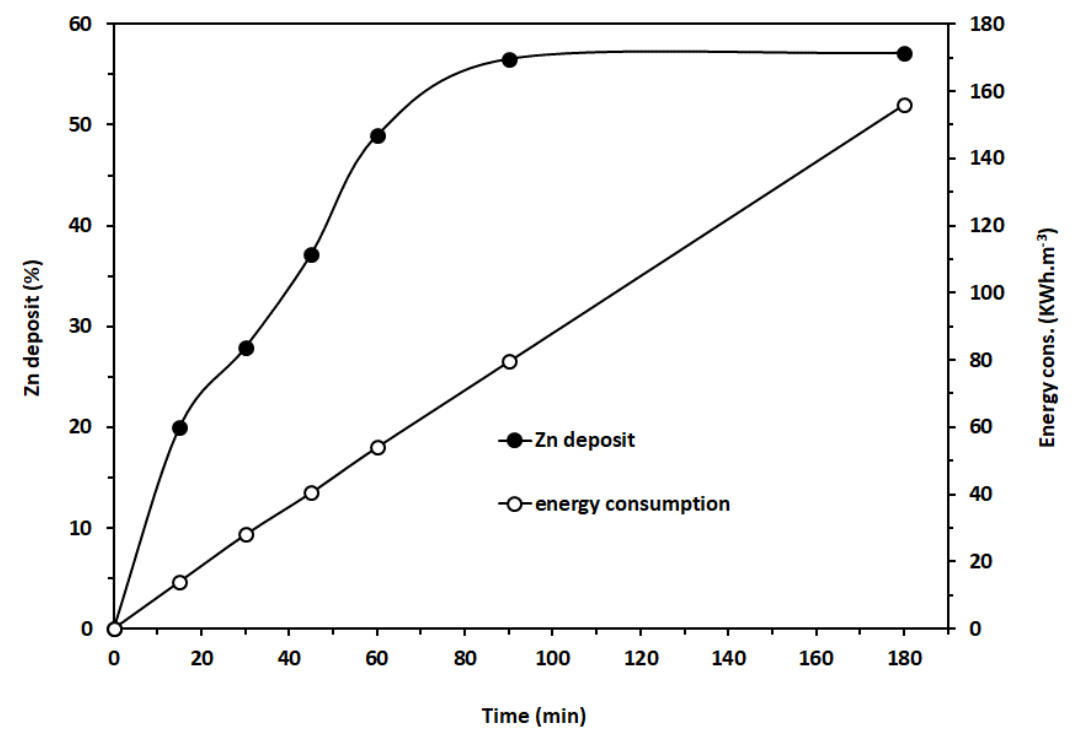

Figure 4. Variation in residual $\mathrm{Zn}$ concentration and effect of energy consumption as a function of time applying a current density of $500 \mathrm{~A} / \mathrm{m}^{2}$.

\subsubsection{Recovery of $\mathrm{MnCO}_{3}$ from PLS-2 Solution}

Using the same principle, iron precipitation assays were carried out with $1.5 \mathrm{SMR}$ of $\mathrm{H}_{2} \mathrm{O}_{2}$ for the oxidation of $\mathrm{Fe}^{2+}$ ions to $\mathrm{Fe}^{3+}$ at $\mathrm{pH}=4$ and ambient temperature. Within this context, nearly $99.9 \%$ of Fe in PLS- 2 was precipitated. A concentration of $2754 \mathrm{mg} \mathrm{Fe} / \mathrm{L}$ was recorded in PLS-2 and a concentration of $2.33 \mathrm{mg} \mathrm{Fe} / \mathrm{L}$ was measured after Fe removal (Table 5). In this step, the concentration 
of Co remained stable, while all $\mathrm{Cu}$ was removed and the concentration of $\mathrm{Ni}$ decreased from 48.4 to $24.1 \mathrm{mg} / \mathrm{L}$.

To obtain a pure manganese solution, zinc precipitation was achieved by adding $\mathrm{Na}_{2} \mathrm{~S}$ ( $2 \mathrm{SMR}$ of $\mathrm{Na}_{2} \mathrm{~S}$ at $\mathrm{pH} 4-5$ ). Under these conditions, up to $100 \%$ of zinc was precipitated (Table 5) and the obtained $\mathrm{ZnS}$ could be added to the first leaching stage for PLS-1 rich in $\mathrm{Zn}$.

The precipitation of $\mathrm{MnCO}_{3}$ was achieved by the addition of $\mathrm{Na}_{2} \mathrm{CO}_{3}$. The quantity of $\mathrm{Na}_{2} \mathrm{CO}_{3}$ was calculated for $1 \mathrm{SMR}$, with $\mathrm{pH} 4.5-5.0$ and at ambient temperature. After rinsing, the collected $\mathrm{MnCO}_{3}$ had a purity of $95 \%$.

\subsection{Economic Evaluation}

Table 9 presents the direct and indirect costs, as well as profit for a basic plant that recycles 8 tons of batteries per day. In this simulation, the cost of shredding was not considered. However, the non-magnetic fraction (plastic, carton, etc.) and the final residue were considered waste products that would need to be transported over $50 \mathrm{~km}$ with a disposal cost of $\$ C A D 75$ per ton of residue. This cost included loading, transport, and landfill calculated at \$CAD 28.2 per ton of batteries. In addition to chemical products, labor costs and utilities costs were the two other important parameters, from an economic point of view, which accounted for 18.5 and $10.0 \%$ of the total direct costs, respectively.

A total cost of \$CAD 1260 per ton was calculated, of which the direct and indirect costs were calculated as \$CAD 725.7 and \$CAD 534.5 per ton, respectively. Regarding the cost simulation, cost distribution was dominated by indirect costs including amortization $(9.6 \%)$, financing $(15.8 \%)$, and marginal social benefits (1.5\%). The revenue was calculated as \$CAD 1359.6 per ton, whereas $\mathrm{Zn}, \mathrm{MnO}_{2}$, and $\mathrm{MnCO}_{3}$ values were estimated as \$CAD 527.4, \$CAD 451.6, and \$CAD 357.8 per ton, respectively.

Figure 5 illustrates the variation in cost as a function of the recovery capacity of the plant. Indirect costs showed an influence on total cost, and costs decreased with the increase in recovery capacity. Total costs were evaluated to be \$CAD 1015 and \$CAD 913 per ton for treatment capacities of 16 and $24 \mathrm{t} /$ day, respectively, equivalent to 40 and $60 \%$ of batteries sold in the Canadian market.

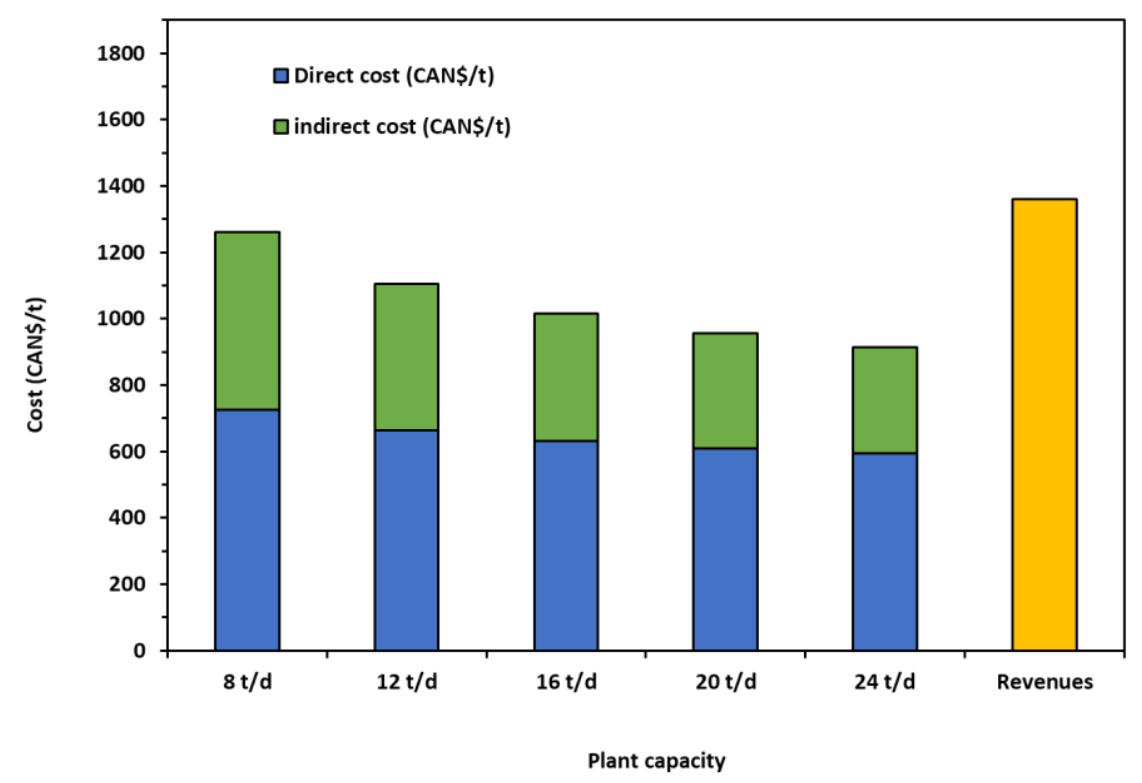

Figure 5. Exploitation costs and revenues depending on the processing capacity of the recovery plant. 
Table 9. Parameters related to hydrometallurgical recovery in spent alkaline battery.

\begin{tabular}{|c|c|c|c|}
\hline Parameters & Values & Units & Cost/profit (\$CAD/t) \\
\hline Direct operating costs & - & - & -725.7 \\
\hline Chemicals & - & - & - \\
\hline $\mathrm{H}_{2} \mathrm{SO}_{4}$ & 0.21 & $\$ C A D / k g$ & -129.0 \\
\hline $\mathrm{NaOH}$ & 0.35 & $\$ C A D / k g$ & -89.3 \\
\hline $\mathrm{Na}_{2} \mathrm{CO}_{3}$ & 0.21 & $\$ C A D / k g$ & -14.7 \\
\hline $\mathrm{H}_{2} \mathrm{O}_{2}$ & 1.60 & $\$ C A D / k g$ & -15.6 \\
\hline $\mathrm{Na}_{2} \mathrm{~S}_{2} \mathrm{O}_{8}$ & 0.30 & $\$ C A D / k g$ & -18.6 \\
\hline $\mathrm{Na}_{2} \mathrm{~S}_{2} \mathrm{O}_{5}$ & 0.31 & $\$ C A D / k g$ & -86.9 \\
\hline $\mathrm{Na}_{2} \mathrm{~S}$ & 0.90 & $\$ C A D / k g$ & -45.7 \\
\hline Labor & - & - & - \\
\hline Unit cost & 25.0 & $\$ C A D / h$ & -115.9 \\
\hline Supervision & 20.0 & $\%$ (labor cost) & -23.2 \\
\hline \multicolumn{4}{|l|}{ Utilities } \\
\hline Unit cost of electricity & 0.07 & $\$ C A D / k W h$ & -27.5 \\
\hline Unit cost of water process & 0.50 & $\$ \mathrm{CAD} / \mathrm{m}^{3}$ & -2.6 \\
\hline Unit cost of fuel & 3.50 & $\$ C A D / M$ Btu & -20.7 \\
\hline Residue management & - & - & \\
\hline Loading and transport cost & 2.50 & $\$ C A D / t$ & -3.3 \\
\hline Transportation cost (estimate of $50 \mathrm{~km}$ ) & 0.15 & $\$ C A D / t / k m$ & - \\
\hline Unit cost of landfill or treatment & 75.0 & $\$ C A D / t$ & -24.9 \\
\hline Maintenance and repairs & 2.00 & $\%$ fixed capital costs/yr & -66.1 \\
\hline Current materials & 0.75 & $\%$ fixed capital costs/yr & -24.8 \\
\hline Laboratory charges & 10 & $\%$ operating labor & -11.6 \\
\hline Patents and royalties & 5.00 & $\$ C A D / t$ & -5.0 \\
\hline Indirect and General costs & & & -534.5 \\
\hline Marginal social benefits & 22.0 & $\%$ operating labor + supervision & -30.6 \\
\hline Amortization & - & - & -189.9 \\
\hline Financing (interest redemption) & - & - & -314.0 \\
\hline Metal revenues & - & - & 1359.6 \\
\hline $\mathrm{Fe}$ & 0.10 & $\$ C A D / k g$ & 22.8 \\
\hline $134 \mathrm{~kg}$ of $\mathrm{MnO}_{2}(85.6 \mathrm{~kg} \mathrm{Mn})$ & 3.37 & $\$ C A D / k g$ & 451.6 \\
\hline $286 \mathrm{~kg}$ of $\mathrm{MnCO}_{3}(136.5 \mathrm{~kg} \mathrm{Mn})$ & 1.25 & $\$ C A D / k g$ & 357.8 \\
\hline $162 \mathrm{~kg}$ of $\mathrm{Zn}$ metal & 3.25 & $\$ C A D / k g$ & 527.4 \\
\hline Profit & - & - & 98.3 \\
\hline
\end{tabular}

\section{Conclusions}

In this study, we established a pilot process for the recycling of metals in spent alkaline batteries, including physical separation techniques and hydrometallurgical steps. Spent batteries were crushed and attrited to separate out and collect the metallic powder. Metallic powder was then treated using sulfuric acid leaching. The first leaching for zinc and a part of manganese included the use of $2 \mathrm{M} \mathrm{H}_{2} \mathrm{SO}_{4}$ for $45 \mathrm{~min}$ at ambient temperature and a solid content of $40 \%(w / v)$. Under these conditions, up to $87 \%$ of zinc was solubilized. In the second leaching step, $0.45 \mathrm{~g} \mathrm{Na}_{2} \mathrm{~S}_{2} \mathrm{O}_{5}$ was added per $1 \mathrm{~g}$ metallic powder in $1.34 \mathrm{M} \mathrm{H}_{2} \mathrm{SO}_{4}$, resulting in up to $97 \%$ of manganese being dissolved. The dissolved manganese was recovered by precipitation in the form of $\mathrm{MnO}_{2}$ and $\mathrm{MnCO}_{3}$, whereas zinc was recovered in metallic form by electrowinning. Notably, the leaching efficacy remained high, even after three cycles of processing with recirculated water. Furthermore, results from our technical and economic simulation indicate that the suggested process for recycling spent alkaline batteries is economically competitive and feasible. It is necessary to highlight that the profits from the process greatly depend on the market 
price of zinc, manganese (IV) oxide, and manganese carbonate. However, despite economic challenges, the process of recycling alkaline batteries reduces negative environmental impacts.

Author Contributions: Conceptualization, J.-F.B., G.M., L.-H.T. and K.T.; methodology, K.T., A.D.J.; software, J.-F.B.; validation, J.-F.B., G.M., L.-H.T. and K.T.; formal analysis, K.T. and A.D.J.; investigation, K.T. and A.D.J.; data curation, A.D.J. and K.T.; writing — original draft preparation, L.-H.T.; writing—review and editing, L.-H.T, K.T., J.-F.B. and G.M.; supervision, J.-F.B. and G.M.; project administration, J.-F.B.; funding acquisition, J.-F.B. All authors have read and agreed to the published version of the manuscript.

Funding: This research was funded by Natural Sciences and Engineering Research Council of Canada, grant number RGPIN-2019-05767.X.

Acknowledgments: The authors thank Call2recycle for samples supporting.

Conflicts of Interest: The authors declare no conflict of interest.

\section{References}

1. Leite, D.D.S.; Carvalho, P.L.G.; de Lemos, L.R.; Mageste, A.B.; Rodrigues, G.D. Hydrometallurgical recovery of $\mathrm{Zn}(\mathrm{II})$ and $\mathrm{Mn}(\mathrm{II})$ from alkaline batteries waste employing aqueous two-phase system. Sep. Purif. Technol. 2019, 210, 327-334. [CrossRef]

2. Ye, G.; Magnusson, M.; Väänänen, P.; Tian, Y. Recovery of Zn and Mn from spent alkaline batteries. In The Minerals, Metals and Materials Series; Springer International Publishing: Berlin, Germany, 2018; Volume F10, pp. 329-341.

3. Abid Charef, S.; Affoune, A.M.; Caballero, A.; Cruz-Yusta, M.; Morales, J. Simultaneous recovery of Zn and $\mathrm{Mn}$ from used batteries in acidic and alkaline mediums: A comparative study. Waste Manag. 2017, 68, 518-526. [CrossRef]

4. Yuliusman; Amiliana, R.A.; Wulandari, P.T.; Ramadhan, I.T.; Kusumadewi, F.A. Selection of organic acid leaching reagent for recovery of zinc and manganese from zinc-carbon and alkaline spent batteries. IOP Conf. Ser. Mater. Sci. Eng. 2018, 333, 012041. [CrossRef]

5. Sayilgan, E.; Kukrer, T.; Civelekoglu, G.; Ferella, F.; Akcil, A.; Veglio, F.; Kitis, M. A review of technologies for the recovery of metals from spent alkaline and zinc-carbon batteries. Hydrometallurgy 2009, 97, 158-166. [CrossRef]

6. Tanong, K.; Coudert, L.; Chartier, M.; Mercier, G.; Blais, J.F. Study of the factors influencing the metals solubilisation from a mixture of waste batteries by response surface methodology. Environ. Technol. 2017, 38, 3167-3179. [CrossRef]

7. Formánek, J.; Jandová, J.; Sís, J. A review of hydromet-allurgical technologies for the recovery of Zn and Mn from spent alkaline and zinc batteries. Chem. Listy 2012, 106, 350-356.

8. Tanong, K.; Tran, L.-H.; Mercier, G.; Blais, J.-F. Recovery of Zn (II), Mn (II), Cd (II) and Ni (II) from the unsorted spent batteries using solvent extraction, electrodeposition and precipitation methods. J. Clean. Prod. 2017, 148, 233-244. [CrossRef]

9. Canada, C.R. Canadians Are Going Green: Call2Recycle Canada Diverts Record Number Of Batteries in 2018. 2019. Available online: https://www.call2recycle.ca/canadians-are-going-green-call2recycle-canadadiverts-record-number-of-batteries-in-2018/ (accessed on 14 February 2020).

10. Recyc-Quebec. Piles et batteries. In Fiches D'information 2019. Available online: https://www.recyc-quebec. gouv.qc.ca/sites/default/files/documents/Fiche-info-piles.pdf (accessed on 14 February 2020).

11. Canada, C.R. Explore the Secret Life of Batteries. 2018. Available online: https://www.call2recycle.ca/explorethe-secret-life-of-batteries/ (accessed on 10 February 2018).

12. Veloso, L.R.S.; Rodrigues, L.E.O.C.; Ferreira, D.A.; Magalhães, F.S.; Mansur, M.B. Development of a hydrometallurgical route for the recovery of zinc and manganese from spent alkaline batteries. J. Power Sources 2005, 152, 295-302. [CrossRef]

13. Chen, W.-S.; Liao, C.-T.; Lin, K.-Y. Recovery Zinc and Manganese from Spent Battery Powder by Hydrometallurgical Route. Energy Procedia 2017, 107, 167-174. [CrossRef]

14. Maryam Sadeghi, S.; Vanpeteghem, G.; Neto, I.F.F.; Soares, H.M.V.M. Selective leaching of Zn from spent alkaline batteries using environmentally friendly approaches. Waste Manag. 2017, 60, 696-705. [CrossRef] [PubMed] 
15. Vellingiri, K.; Tsang, D.C.W.; Kim, K.H.; Deep, A.; Dutta, T.; Boukhvalov, D.W. The utilization of zinc recovered from alkaline battery waste as metal precursor in the synthesis of metal-organic framework. J. Clean. Prod. 2018, 199, 995-1006. [CrossRef]

16. Gallegos, M.V.; Peluso, M.A.; Sambeth, J.E. Preparation and Characterization of Manganese and Zinc Oxides Recovered from Spent Alkaline and Zn/C Batteries Using Biogenerated Sulfuric Acid as Leaching Agent. JOM 2018, 70, 2351-2358. [CrossRef]

17. Furlani, G.; Moscardini, E.; Pagnanelli, F.; Ferella, F.; Vegliò, F.; Toro, L. Recovery of manganese from zinc alkaline batteries by reductive acid leaching using carbohydrates as reductant. Hydrometallurgy 2009, 99, 115-118. [CrossRef]

18. Petranikova, M.; Ebin, B.; Mikhailova, S.; Steenari, B.M.; Ekberg, C. Investigation of the effects of thermal treatment on the leachability of $\mathrm{Zn}$ and $\mathrm{Mn}$ from discarded alkaline and $\mathrm{Zn}-\mathrm{C}$ batteries. J. Clean. Prod. 2018, 170, 1195-1205. [CrossRef]

19. Sobianowska-Turek, A.; Szczepaniak, W.; Maciejewski, P.; Gawlik-Kobylińska, M. Recovery of zinc and manganese, and other metals ( $\mathrm{Fe}, \mathrm{Cu}, \mathrm{Ni}, \mathrm{Co}, \mathrm{Cd}, \mathrm{Cr}, \mathrm{Na}, \mathrm{K})$ from $\mathrm{Zn}-\mathrm{MnO} 2$ and $\mathrm{Zn}-\mathrm{C}$ waste batteries: Hydroxyl and carbonate co-precipitation from solution after reducing acidic leaching with use of oxalic acid. J. Power Sources 2016, 325, 220-228. [CrossRef]

20. Sayilgan, E.; Kukrer, T.; Yigit, N.O.; Civelekoglu, G.; Kitis, M. Acidic leaching and precipitation of zinc and manganese from spent battery powders using various reductants. J. Hazard. Mater. 2010, 173, 137-143. [CrossRef]

21. Ivanov, I. Increased current efficiency of zinc electrowinning in the presence of metal impurities by addition of organic inhibitors. Hydrometallurgy 2004, 72, 73-78. [CrossRef]

22. Gasper, P.; Hines, J.; Miralda, J.P.; Bonhomme, R.; Schaufeld, J.; Apelian, D.; Wang, Y. Economic feasibility of a mechanical separation process for recycling alkaline batteries. J. New Mater. Electrochem. Syst. 2013, 16, 297-304. [CrossRef]

23. Metahni, S.; Coudert, L.; Blais, J.-F.; Tran, L.H.; Gloaguen, E.; Mercier, G.; Mercier, G. Techno-economic assessment of an hydrometallurgical process to simultaneously remove As, $\mathrm{Cr}, \mathrm{Cu}, \mathrm{PCP}$ and PCDD/F from contaminated soil. J. Environ. Manag. 2020, 263, 110371. [CrossRef]

24. Ulrich, G.D. A Guide to Chemical Engineering Process Design and Economics; John Wiley \& Sons: New York, NY, USA, 1984.

25. Peters, M.S.; Timmerhaus, K.D. Plant Design and Economics for Chemical Engineers, 4th ed.; McGraw-Hill: New York, NY, USA, 1991.

26. Almeida, M.F.; Xará, S.M.; Delgado, J.; Costa, C.A. Characterization of spent AA household alkaline batteries. Waste Manag. 2006, 26, 466-476. [CrossRef]

27. USEPA. Hazardous Waste Charateristics. 2009. Available online: https://www.epa.gov/sites/production/files/ 2016-01/documents/hw-char.pdf (accessed on 10 February 2018).

28. Blais, J.F.; Mercier, G.; Tanong, K.; Tran, L.H.; Coudert, L. Method for recycling Valuable Metals from Spent Batteries. U.S. Patent 20170170532A1, 15 June 2017.

29. Bøckman, O.; Østvold, T. Products formed during cobalt cementation on zinc in zinc sulfate electrolytes. Hydrometallurgy 2000, 54, 65-78. [CrossRef]

30. Safarzadeh, M.S.; Moradkhani, D.; Ashtari, P. Recovery of zinc from Cd-Ni zinc plant residues. Hydrometallurgy 2009, 97, 67-72. [CrossRef]

31. George, P.; Demopoulos, L.R.; Wang, Q. Method for Removing Manganese from Acidic Sulfate Solution. U.S. Patent 6391270B1, 21 May 2002.

32. Zhang, Z.-Y.; Zhang, F.-S.; Yao, T. An environmentally friendly ball milling process for recovery of valuable metals from e-waste scraps. Waste Manag. 2017, 68, 490-497. [CrossRef]

33. Poinsignon, C.-J.-L.; Tedjar, F. Method for Electrolytical Processing of Used Batteries. European Patent 0620607A1, 19 October 1994.

(C) 2020 by the authors. Licensee MDPI, Basel, Switzerland. This article is an open access article distributed under the terms and conditions of the Creative Commons Attribution (CC BY) license (http://creativecommons.org/licenses/by/4.0/). 